\title{
Introducing Complex Situations in Primary Education: Their Impact on Student's Results in Terms of Efficiency
}

\author{
Alphonse Sebaganwa ${ }^{1, *}$ \\ ${ }^{1}$ Kigali Institute of Education, Rwanda \\ *Correspondence: Tel: 250-785-137-690 E-mail: sebaganwa_al@yahoo.fr
}

Received: May 21, 2013

Accepted: July 11, 2013 Published: August 19, 2013

doi:10.5296/ije.v5i3.4146

URL: http://dx.doi.org/10.5296/ije.v5i3.4146

\begin{abstract}
This paper examined the efficiency of using complex situations in teaching Science and Elementary Technology in 20 primary schools, 38 classes ( only fourth years), located in Huye district in Rwanda. The sample was divided into four groups: 9 classes practiced the "teaching situations”, 9 dealt with "integration situations”, 9 mixed "teaching and integration situations" and 11 classes made a "reference group" that did not use any of those approaches. One pre-test and three post-tests have been done by learners from those classes during the 2012 school year. Every test had a "resource" test and a "situation" test with a similar level of difficulties. The analysis indicated progressive increase of marks, especially, for the classes which practiced the "integration situations". The findings showed a priority of starting with the "integration situations” for the development of the learner's autonomy and of a cognitive development.
\end{abstract}

Keywords: complex situations; efficiency; teaching science; education; Rwanda 


\section{Introduction}

This paper explores the use of the complex situations in teaching Science and Elementary Technology (SET) in 20 primary schools (Huye District; Rwanda) and its impact on students' results in terms of efficiency.

This research is focused on the question of how to introduce complex situations in teaching and learning STE aiming to maximise efficiency. Indeed, some scholars De Ketele and Postic (1988), Roegiers (2010) recognize two different ways complex situations may be introduced at school. These authors understand complex situations as follows:

- "teaching situations" are situations of discovery and/or research. They are often conducted in small groups to construct learning, knowledge and know-how. The quoted authors describe such situations as a process largely inspired by social constructivism.

- "integration situations" are suggested to be complex and offered at the end of learning a specific topic (usually after 5 or 6 weeks). In addition each student is expected to utilize his/her prior acquisitions. The cited authors define integration situations as product that match with the profile of expected output.

This study attempts to address the following main questions:

-How and to what extent the introduction of teaching situations have an impact on student's results in learning SET?

-How and to what extent the introduction of integration situations influence student's results in learning SET?

-How and to what extent introducing the two approaches simultaneously, impact on student's results in learning SET?

\section{Some Elements of Literature}

Roegiers (2011) ascertains that teacher's efforts to implement innovations are limited, especially when an education system multiplies innovations, or at least in terms of teaching some important skills. The author shows that due to this ineffectiveness, one may wonder whether schools produce thinkers, doers, or furthermore relevant actors in society, or whether they simply produce performers and consumers, because of a narrowly defined concept of effective education. Further, Roegiers request if young people have access to tools, not only to fit into the job market, but also and especially to think of alternative professional futures.

Dumay and Dupriez (2009) states that the concept of effective teaching refers to the question of mechanisms and practices that promote student learning and enhance their performance in an educational context. According to them, several research topics have fueled the debate on teaching effectiveness since the end of World War II. He says that beyond their apparent diversity, and their various disciplinary roots, these research areas are all trying to identify effective practices. In other words, the practice may affect the quality and amount of student 
learning.

Research conducted in the Organisation for Economic Co-operation and Development (OECD) countries, nearly found that one of five students does not reach the minimum level of basic skills needed to function in today's society. The likelihood that students from lower socio-economic backgrounds are lower functioning is twice as high, which means that personal or social circumstances are obstacles to achieving their educational potential, indicating a lack of equity (OECD, 2012).

In Africa, many countries are often absent in international rankings, for which educational quality is made difficult to attain because of a less than conducive economic context. These countries also, classified as "less developed" in terms of economic development, face an urgent challenge: to provide the entire population with basic education, an essential ingredient for economic development.

Similarly, the ratio of UNESCO (2010) shows that generalized and rigorous educational reform is essential in African countries to achieve a democratized basic education based on the principles of social justice, equity and social inclusion, which provides a wide range of possibilities to a wider range of students and empowers all students to contribute to a stable society.

Roegiers (2001) demonstrates that results from previous studies related to the integration of student learning and as such, the assessment of student learning by integration situations of learning shows that students who practice such situations in classes in Tunisia perform 3-6 points better ( 20 points) than other students not participating in integration situations. Also, the results show that there is better retention of acquired knowledge over time; in particular learning resources are more stable from June to September, while in general there is a decline of $25 \%$ to $30 \%$ between June and September. These regressions are low for students in grades practicing integration situations. They are of the order of $1 \%$ to $5 \%$ and sometimes even positive according to the author.

Didiye et al. (2005) compare results from Mauritania and Tunisia, and confirm the main observed trends based on a gain of 2 to 5 points out of 20 trials on average for the "situations" tests among those students who practiced complex situations, while students of the same classes as well as students who have followed the old curriculum were successful in "resources" tests. In addition, the cited Unesco report shows that in Cameroon, 75 pilot schools have introduced the integration situations during the 2003-2004 school year. This Unesco evaluation reports that the learners results were excellent. Based on that report, Amin (2004) has shown that in Cameroon the practice of remediation for a year causes a significant increase in the sixth year test entry and the combination of "remediation-integration" will double this increase.

Aden and Roegiers (2003), show that, in terms of efficiency, complex situations practice leads to a gain that is around 3 points out of 20 for students in the experimental classes.

A similar study has been conducted in Rwanda in which the political and educational context is described in the next section. 


\section{The Political and Educational Context in Learning SET in Rwanda}

Legendre (1994) contends that in a social context that promotes science and technology education as a tool for adaptation and social integration, multiple failures and difficulties encountered by students in learning the sciences pose significant challenges for teachers and trainers. Similarly, the increasing importance of science and technology in our lives has led to consider scientific training as one of the major challenges of society's future.

In the specific context of Rwanda, the teaching of science and technology is becoming more and more a concern of educational policy makers. This is because of an extremely low level of adoption and integration of science and technologies in the socio-economic life, and a lack of technically qualified professionals at all levels (Minifin, 2000).

For example, the 2010-2017 government program for education states that Rwanda plans to have adequate, highly skilled scientists and technicians to meet the needs of the national economy. It is therefore necessary to produce, distribute and acquire scientific skills as well as technological innovations and then integrate them into the dynamic of social and economic development.

The project "Support to Basic Education" of the Belgian Technical Cooperation in Rwanda (1996) in its report, recognizes that science and technology are becoming increasingly prominent sectors in the Rwandan education system. The Rwandan education system is concerned with making students capable of critical thinking and scientific reasoning.

At the primary level, the report argues students are thought to observe the environment around them and are encouraged to learn by manipulation of objects. A course entitled Science and ElementaryTechnology (SET) has recently been incorporated into the curriculum. However, there is a lack of appropriate equipment and competent teachers for effective teaching of science and technology, according to the report. The same report indicates that the participation of girls in science and technology is always much lower because of the influence of gender stereotypes. It is therefore necessary to not only establish clear and tangible incentives for teachers of science, mathematics and technology and for students at all levels, but especially for girls.

Pedagogical practices implemented in education, for half a century, have been and remain largely transmissive content, which would at least in part, deprived the country of scientific and technological skills that could have modernized its economy.

But recently in 2010, during the revision of the SET curriculum and the introduction of the "complex situations" approach in science education in Rwanda, a new organization of content has been implemented along with a redefinition of the performance profile of elementary students (NCDC, 2010) that exit from primary school as follows:

1) Understand different ideas in written, oral English and Kinyarwanda texts;

2) Express him / herself by writing and talking in English and Kinyarwanda;

3) Posses basic knowledge of mathematics, science and technology and apply knowledge in 
solving problems that occur in his / her daily life;

4) Show Appropriate attitude related to environmental conservation, interaction with others and emotion management;

5) Show his / her role in economic growth;

6) Show appropriate civic, moral, religious, esthetic values and physical fitness;

7) Good Habits That Show protect his / her health and others' health;

8) Show Good Habits of hygiene on his / her body and every where he / she is;

9) Strive for the cultivation of tolerance, peace, unity and reconciliation Among Rwandans;

10) Apply knowledge and skills different Acquired in solving problems in his / her daily life;

11) Acquire skills needed to studies in an ordinary level of secondary education.

The novelty of this output profile compared to the previous one, is that it includes in points 3 and 10 problem solving in everyday life, according to the proposed method of learning by complex situations in science education in primary school.

Indeed, it is in this context of school education policy in Rwanda that this study was conducted.

\section{Methodology, Procedures and Results of the Research}

The research concerned a sample of 38 classes of the fourth year of primary school (10 years old) from 20 schools in the district of Huye (Southern Rwanda). It aims to analyze the impact of each complex situations use in terms of efficiency, measured by student achievement. This article discusses the results in terms of effectiveness. 38 classes (about 1500 students) are representative of the public school population as well as that of the private schools. Before this research, none of the participating teachers used complex situations. The classes were divided into 4 groups, according to whether they developed the practice of teaching situations and / or situations of integration, as illustrated in the following table.

Table 1: Differentiated Practices of "Complex Situations"

\begin{tabular}{llll}
\hline & \multicolumn{2}{l}{ Practical teaching situations } & \\
\cline { 2 - 4 } & NO & YES \\
\hline $\begin{array}{l}\text { Practical } \\
\text { integration } \\
\text { situations }\end{array}$ & NO & $\begin{array}{l}\text { Group 1: 9 classes } \\
\text { (Control Group) }\end{array}$ & Group 2: 11 classes \\
& YES & Group 3: 9 classes & Group 4: 9 classes \\
\hline
\end{tabular}

Before launching the research, none of the participating classes practiced either teaching situations or integration situations. Meanwhile, the researcher was not a specialist in teaching 


\section{Macrothink

situations nor in integration situations. We are therefore, in a relatively neutral about the past of the researcher (who is also the trainer of teachers) about the past and experimental classes.

Teachers received a three (3) day training on teaching situations (groups 2 and 4), and a three (3) day training on integration situations (groups 3 and 4). These trainings were conducted by the researcher. Training focused on the same content in all classes for the four groups: hand tools and their maintenance, water and environment, health.

To ensure that the initial level in the four groups is equivalent, two pre-tests were administered to students in 38 classes, before starting the experiment:

- One "resources" test on knowledge and know-how

- One "complex situations" test on the use of these complex situations.

In addition to the pre-test, three other tests were conducted to measure learning of resources and complex situations: one after 4 weeks of learning (post-test 1, week 5), another after 9 weeks of learning (post-test 2, week 10), and the third after 8 months of learning (post-test 3).

The following is an example of a complex situation test:

Level: Primary 4

Date: January, $27^{\text {th }} 2012$

Lesson: Science and elementary technology

Topic I: Hand tools and their maintenance

Competence: By the end of this topic the learner will be able to:

-Use and maintain simple agriculture, carpentry and masonry hand tools.

\section{Pre-test}

\section{Situation: school desks}

The principal of our school wants to produce new pupil's desks by using the forest big trees near the school. But he doesn't know the tools to use and how to maintain them.

Task: advise the principal in order to find a) tools that he will use to make desks from trees. b) tools that he will use to plant other trees.

\section{To the attention of pupils:}

-to read with attention the situation

-to answer by simple words

-to respect quiz time

-to make a clean copy 


\section{Situation support document}
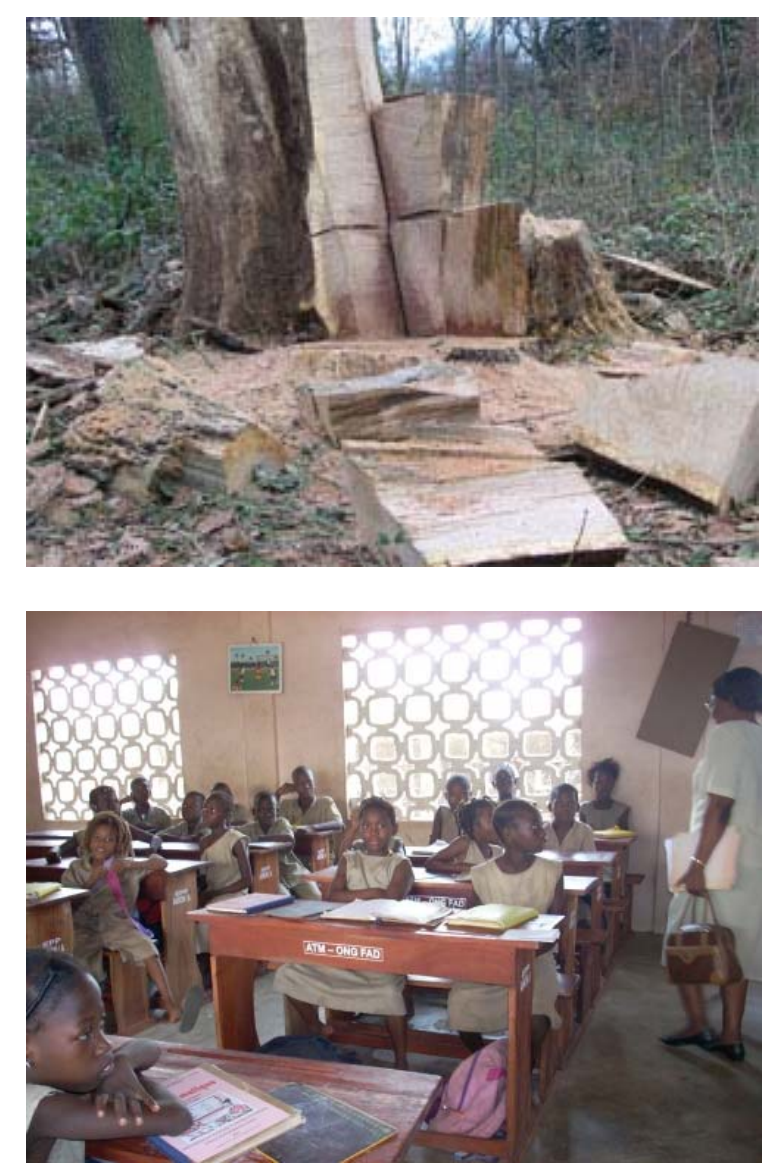

This one is an example of a "resource" test:

\section{Level: Primary 4}

Date: January, $27^{\text {th }} 2012$

Lesson: Science and elementary technology

Topic I: Hand tools and their maintenance

Competence: By the end of this topic the learner will be able to:

-Use and maintain simple agriculture, carpentry and masonry hand tools.

\section{Pre-test}

\section{Resources}

Question

Identify a) 2 tools of a farmer

b) 1 tool of a carpenter

c) 2 tools of a manson

To the attention of pupils:

-to read with attention the questions

-to answer by simple words

-to respect quiz time: 40 minutes

-to make a clean copy 


\section{Mll Macrothink}

The results from the pre-test were pretty low: the average of all classes varied between $1 / 10$ and 4.5/10. The average score from the "resources" pre-test was 4/10, and the average for the "situations" test was 3.5/10. For methodological reasons, low pre-test scores is convenient in order to mitigate the impact of any side effects, meaning that it is more difficult to show improvement for a student starting from a high score than for a student starting with a low score. For example, it is more difficult to earn a point for a student from 8/10 compared to another student from $2 / 10$.

To take into account this "edge effect", and neutralize it, the results from each group were compared using a logarithmic regression.

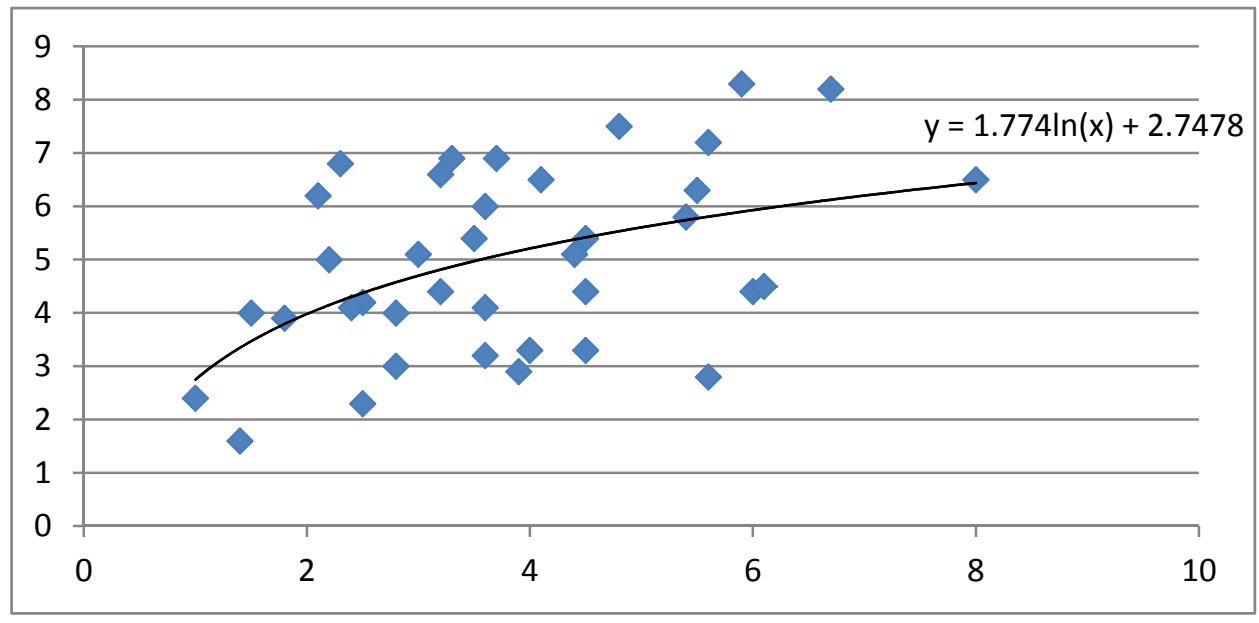

Figure 1: Example of Regression Results for the Post-test 1 "Resources"

In this curve, each point represents one of 38 classes, and the abscissa is the average scores at pre-test "resources" and the ordinates are the average scores to post-test 3 on resources also. The point at the top left means for example that, in this class, the average has not earned 5 points (from 2/10 to 7/10), but a little less than 3 points (the difference between 7 and curve regression).

The points located above the curve represent classes in which students earned more than the average (the average is represented by the curve). The points located below the curve represent classes in which students earned less than the average.

Given that the average results of five schools in the pre-test ranged from 0 (3 cases) to 0.2 out of 10 , these schools were removed from the initial sample. Some outliers were also cleaned from the files.

Results presented below are the gains as they appear after correction by the regression. They come from a group of student results within a file "medium class". They do not come from the files of students.

There are adjusted gains (residuals) of each group testing "resources", the number of points calculated each time from the pre-test. 
Table 2: Evolution of Notes for Each Category in Terms of Mastery of the Resources 2013, Vol. 5, No. 3

\begin{tabular}{|c|c|c|c|}
\hline \multirow{2}{*}{$\begin{array}{l}\text { Relative gain of each group to a } \\
\text { "resource" test / Post-test } 1\end{array}$} & & \multicolumn{2}{|c|}{ Practical teaching situations } \\
\hline & & NO & YES \\
\hline \multirow[t]{2}{*}{ Practical integration situations } & NO & $\begin{array}{l}\text { Control: } \\
+2.14 \text { pts }\end{array}$ & $\begin{array}{l}\text { Teaching situations: } \\
+\mathbf{1 . 0 9} \text { pts }\end{array}$ \\
\hline & YES & $\begin{array}{l}\text { Integration } \\
\text { situations: } \\
\text { +1.2 pts }\end{array}$ & $\begin{array}{l}\text { Teaching situations + } \\
\text { Integration situations: + } \\
\mathbf{0 . 1 2}\end{array}$ \\
\hline
\end{tabular}

\begin{tabular}{|c|c|c|c|c|}
\hline \multirow{2}{*}{$\begin{array}{l}\text { Relative gain of each group to a } \\
\text { "resource" test / Post-test } 2\end{array}$} & & \multicolumn{3}{|c|}{ Practical teaching situations } \\
\hline & & NO & YES & \\
\hline \multirow[t]{2}{*}{ Practical integration situations } & $\mathrm{NO}$ & $\begin{array}{l}\text { Control: } \\
+2.11 \text { pts }\end{array}$ & $\begin{array}{l}\text { Teaching situations: } \\
+\mathbf{0 . 6 8} \text { pts }\end{array}$ & \\
\hline & YES & $\begin{array}{l}\text { Integration } \\
\text { situations: } \\
+2.22 \text { pts }\end{array}$ & $\begin{array}{l}\text { Teaching situations } \\
\text { Integration situations: } \\
+\mathbf{1 , 2 8}\end{array}$ & + \\
\hline
\end{tabular}

Relative gain of each group to a "resource" test/ Post-test 3

\begin{tabular}{llll}
\hline & NO & YES \\
Practical integration situations & NO & Control: & Teaching situations: \\
& & $\mathbf{+ 1 . 2 8} \mathbf{~ p t s}$ & $\mathbf{+ 1 . 3 7} \mathbf{p t s}$ \\
& YES & Integration & Teaching situations $\quad+$ \\
& & situations: & Integration situations: \\
& +2.35 pts & $\mathbf{+ 0 . 0 1} \mathbf{~ p t s}$ \\
\hline
\end{tabular}

Following figure shows these results (assuming that each class starts from the average score, that is to say an identical score of 4 out of 10 points). 


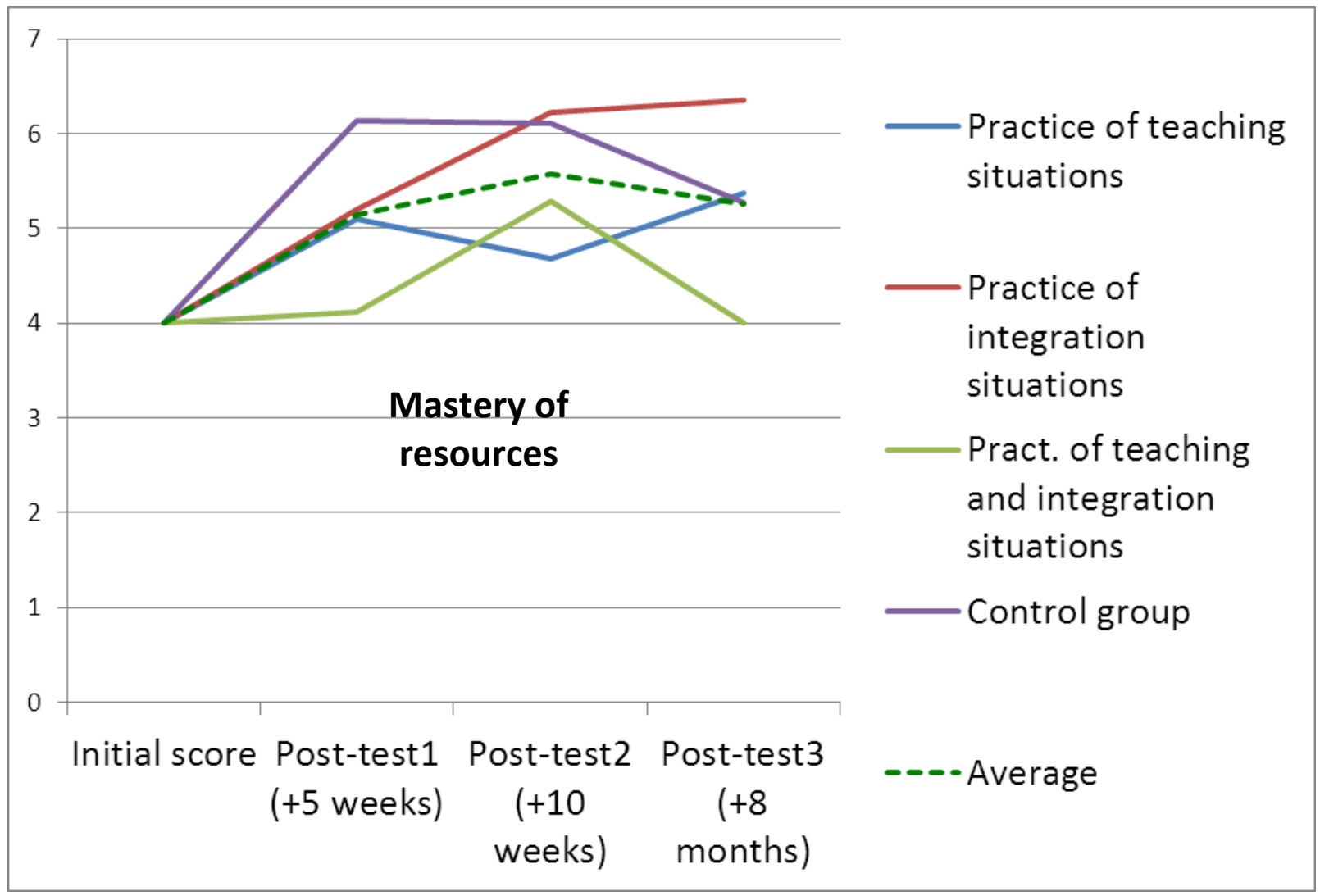

Figure 2: Progress of All Categories in Terms of Mastery of Resources

In this figure, the abscissa is the average scores to all tests "resources" and the ordinates are the average scores on resources also from 0 to 7.

From the observation demonstrated in this table, we can identify the following comments:

All categories progress similarly in terms of mastery of resources: the difference between the results of two groups doesn't exceed 2 points out of ten.

No group loses performance tests "resources." However, the introduction of any work on complex situations, whatever its form, is reflected by the first weeks delay in the mastery of resources.

The increase of the average test results over the four tests is an expected increase: there is a marked increase as of post-test 2, then a small decline due to the fact that the last post-test is administered after a significant period of time.

In the control group, there is a decline in performance after 8 months (part of this can be seen as the effect of major holidays). This decrease is even more marked in the group "teaching situations+ integration situations".

In contrast, for the "integration situations" group, scores continue to rise slightly on mastering resources, even after 8 months. The "teaching situations" group returns for its share in the control group.

The simultaneous introduction of teaching situations+ integration situations affects the mastery 
of resources.

After the results of 'resources' tests, we present in the following table the relative gains in points of each group to an event type "situation".

Table 3: Evolution of Scores for Each Category in Terms of Mastery of Situations

\begin{tabular}{|c|c|c|c|c|}
\hline \multirow{2}{*}{$\begin{array}{l}\text { Relative gain of each group } \\
\text { "situations" test/ Post-test } 1\end{array}$} & \multirow{2}{*}{ to a } & \multicolumn{3}{|c|}{ Practical teaching situations } \\
\hline & & NO & YES & \\
\hline \multirow[t]{2}{*}{ Practical integration situations } & NO & $\begin{array}{l}\text { Control: } \\
+\mathbf{0 . 0 8} \text { pts }\end{array}$ & $\begin{array}{l}\text { Teaching situations: } \\
\mathbf{- 1 . 2 3} \text { pts }\end{array}$ & \\
\hline & YES & $\begin{array}{l}\text { Integration } \\
\text { situations: } \\
+\mathbf{4 . 3 2} \text { pts }\end{array}$ & $\begin{array}{l}\text { Teaching situations } \\
\text { Integration situations: } \\
\mathbf{- 1 . 9 0 ~ p t s ~}\end{array}$ & + \\
\hline
\end{tabular}

Relative gain of each group to a

"situations" test/ Post-test 2

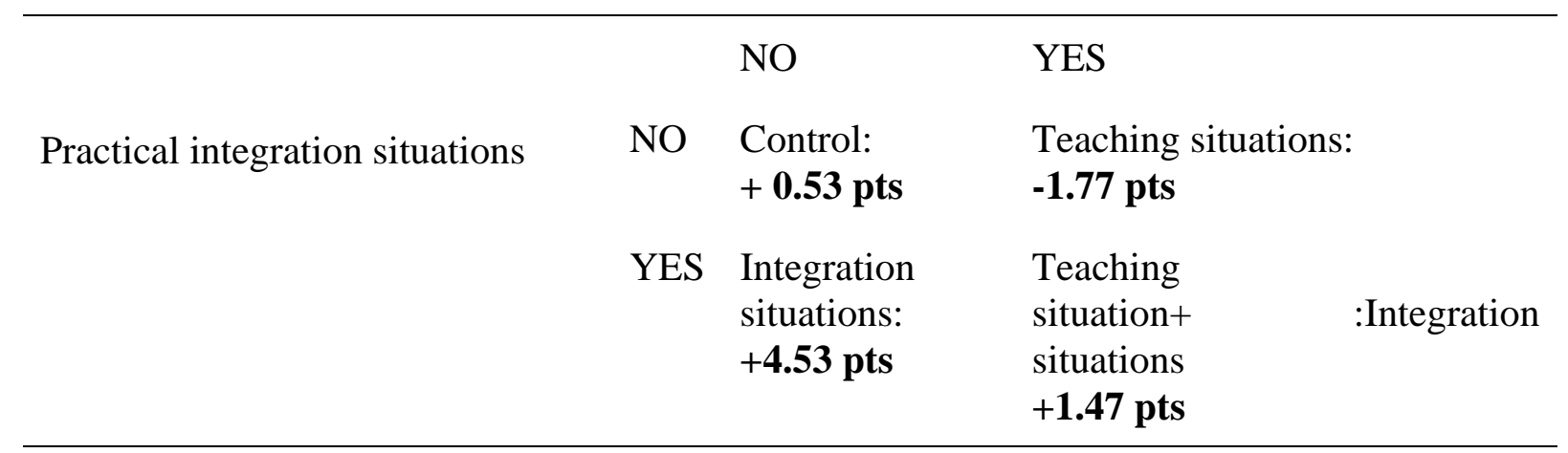

Practical teaching situations

\begin{tabular}{|c|c|c|c|c|}
\hline \multirow{2}{*}{$\begin{array}{l}\text { Relative gain of each group to a } \\
\text { "situations" test/ Post-test } 3\end{array}$} & & \multicolumn{3}{|c|}{ Practical teaching situations } \\
\hline & & NO & YES & \\
\hline \multirow[t]{2}{*}{ Practical integration situations } & NO & $\begin{array}{l}\text { Control: } \\
+0.23 \text { pts }\end{array}$ & $\begin{array}{l}\text { Teaching situations: } \\
\mathbf{- 0 . 1 6} \text { pts }\end{array}$ & \\
\hline & YES & $\begin{array}{l}\text { Integration } \\
\text { situations: } \\
\text { +3.31 pts }\end{array}$ & $\begin{array}{l}\text { Teaching situations } \\
\text { Integration situations: } \\
\mathbf{- 0 . 3 3 ~ p t s}\end{array}$ & + \\
\hline
\end{tabular}

The following figure shows these results (assuming that each class starts from the average score, that is to say an identical score of 3.5 points out of ten). 


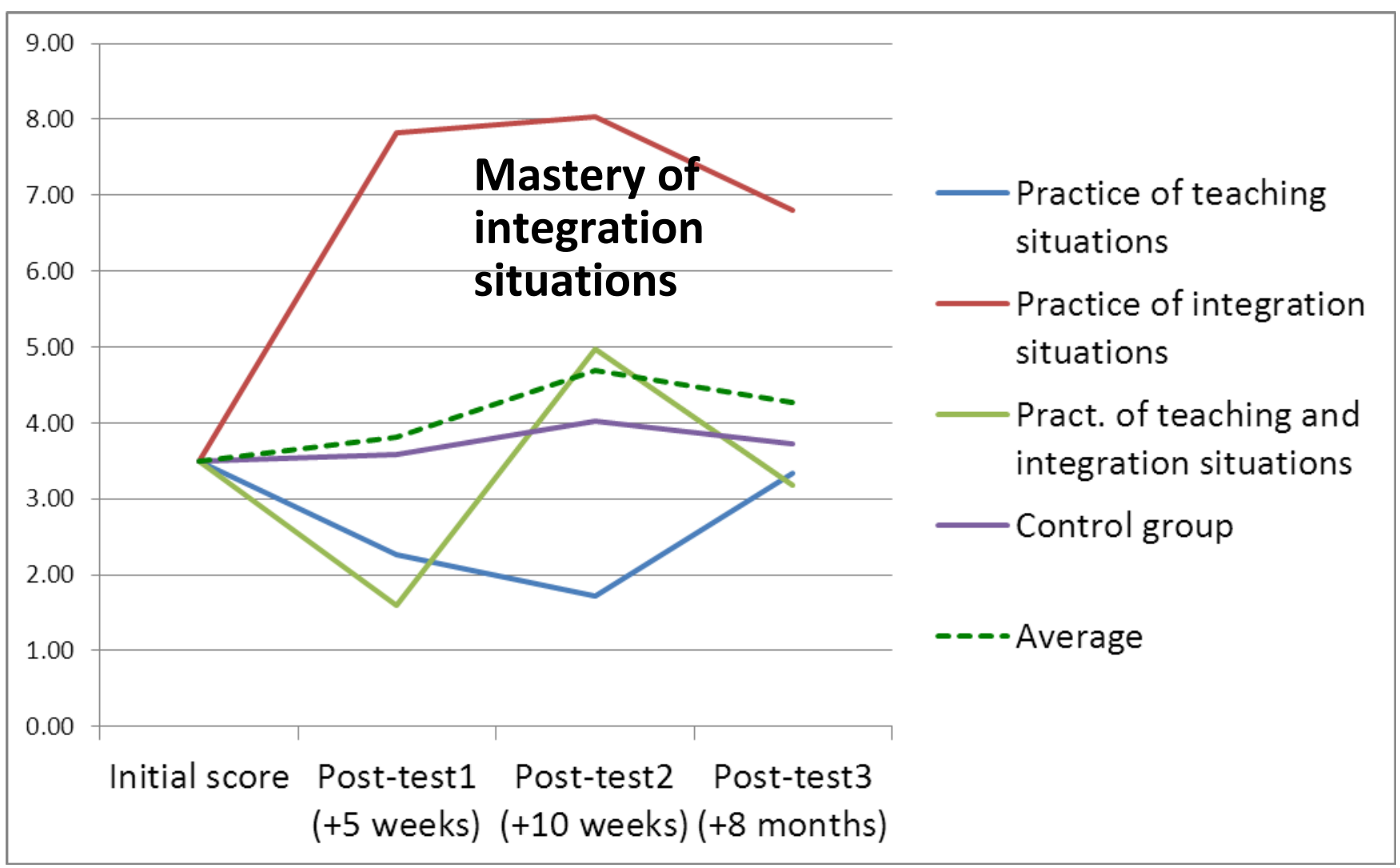

Figure 3: Progress of All Categories in Terms of Mastery of Complex Situations

In this figure, the abscissa is the average scores to all tests "situations" and the ordinates are the average scores on situations also from 0 to 9.

From the observation of this figure, we can identify the following comments:

- Differences in results between groups are much more prominent than for the mastery of resources.

- After 8 months, all categories begin to stagnate, except the "downstream situations" or “integration situations”.

- The increase of the average test scores over the four tests is an expected increase: results increase for the post-test 2 , and then there is a small decline in scores due to the fact that the last post-test (post-test 3 ) is administered so late.

- $\quad$ The progression of the "integration situations only" group increased dramatically after 5 or 10 weeks (almost 70\%), and then flexes a little after 8 months, but remaining at a high level of mastery.

- The progression of the "teaching situations+integration situations" group follows the same trend, but with a delay (performance in situations begins to decline after 5 weeks before climbing, and then falling again).

- Nothing changed significantly in the control group in complex situations mastery (as one would expect). 
- The only category for which practical situations starts with lower performance after 5 and 10 weeks is that of "teaching situations" before returning to its initial level after 8 months. It is as if their energy was going into a new learning mode, and it was only after a few months that it resulted in improved results.

After observation of the two graphs, we can identify the following trends.

- The introduction of practical integration situations only has beneficial effects when there is both mastery of resources as well as mastery of situations; both short term and longer term.

- The introduction of practical teaching situations has little long-term effects on student results, whether related to the mastery of resources or the mastery of complex situations. The limited effects observed are over medium or long term, but not short-term. This seems to be a lag time during which behaviors are installed, and are effective at the end of the latency period. Thus, we see some sort of "delay" effect that comes into plays in this category.

- The simultaneous introduction of practical integration situations and teaching situations seems inefficient for the evolution of educational outcomes, at least on a short-term basis. It is as if the beneficial effect of the introduction of practical integration situations not retained after the introduction of teaching situations.

- Regarding the control group, there is a small straw fire at the mastery of resources in the next few weeks of learning, but results stagnate for mastery of complex situations: it is as if these classes were not engaged in cognitive dynamics.

\section{Elements of Conclusion}

It seems clear from these results that what could advance student performance is the introduction of integration situations and solving them individually, much more than the teaching situations solved in small groups. Is this to say that we should remove these teaching situations from classroom practice? It is premature to say. On one hand, the effects of teaching situations practice may extend beyond the eight (8) month time interval studies, and therefore, long-term effects would need to be tested. On the other hand, the only effects measured are those of student achievement. There are other possible positive effects such as work habits and learner autonomy, that were not measured but that could be an advantage of the practice of teaching situations.

We could also say why not immediately introduce the two types of situations? Just consider the tables to answer the question. Probably few educational systems are able to integrate the two innovative techniques at once. The results suggest that it is first necessary to instil the integration situations, and progressively teaching situations, at least in similar context to that in Rwanda. 


\section{References}

Aden, H.M., \& Roegiers, X. (2003). A quels élèves profite l'approche par les compétences de base? Etude de cas à Djibouti.

Amin, M.E. (2004). The Evaluation of the Pilot Experiment on the Reduction of Class Repetition in Cameroon Primary Schools. MINEDUC/ADB: Yaoundé.

Belgian Technical Cooperation (1996). Support to basic education. Retrieved from: http://www.btcctb.org/doc/UPL-2007010517525320946.pdf

De Ketele, J-M., \& Postic, M. (1988). Observer les situations éducatives. Paris: PUF

Dumay, X., \& Dupriez, V. (2009). L'efficacité dans l'enseignement. Promesses et zones d'ombre. Bruxelles: De Boeck.

Legendre, M-F. (1994). Problématique de l'apprentissage et de l'enseignement des sciences au secondaire: un état de la question. Revue des sciences de l'éducation, 20(4), 657-677.

Ministry of Education (2010). Science and Elementary Technology. Curriculum for upper primary, Kigali.

Ministry of planning and finance (2002). Rwanda 2020 vision, Kigali.

OECD (2012). Equity and Quality in Education: Supporting Disadvantaged Students and Schools. http://dx.doi.org/10.1787/9789264130852-en

Peyser, A., Gerard, F.-M., \& Roegiers, X. (2006). Implementation of a pedagogy of integration: some toughts based on a text book elaboration experience in Vietnam. Planning and changing, 37(1 \& 2), 37-55.

Roegiers, x. (2001). Une pédagogie de l'intégration. Compétences et intégration des acquis dans l'enseignement. Bruxelles, De Boeck Université.

Roegiers, x. (2003). Des situations pour intégrer les acquis scolaires. Bruxelles, De Boeck Université.

Roegiers, X. (2010). Pedagogy of integration. Education and training systems at the heart of our societies. Brussels, ed. De Boeck University.

Roegiers, X. (2011). Curricula et apprentissages au primaire et au secondaire. La pédagogie de l'intégration comme cadre de réflexion et d'action. Bruxelles: De Boeck.

Savin-Badeu, M., \& Major, C.H. (2004). Foundations of problem-based learning. Buckingam: S.R.H.E, Open University press.

Unesco (2010). World data of education. Retrieved from http://www.ibe.unesco.org/fileadmin/user_upload/Publications/WDE/2010/pdf-versions/ Cameroon.pdf 


\section{Copyright Disclaimer}

Copyright reserved by the author(s).

This article is an open-access article distributed under the terms and conditions of the Creative Commons Attribution license (http://creativecommons.org/licenses/by/3.0/). 